\title{
Ectoine accumulation and osmotic regulation in Brevibacterium linens
}

\author{
T. Bernard, ${ }^{1 *}$ M. Jebbar, ${ }^{1}$ Y. Rassouli, ${ }^{1}$ S. Himdi-Kabbab,${ }^{2}$ J. Hamelin $^{2}$ and C. Blanco ${ }^{1}$ \\ ${ }^{1}$ Laboratoire de Génétique et Physiologie Microbiennes (CNRS URA 256) and ${ }^{2}$ Groupe de Recherche de \\ Physicochimie Structurale (CNRS URA 704), Université de Rennes I, Campus de Beaulieu, 35042 Rennes, France
}

(Received 5 June 1992; revised 1 September 1992; accepted 4 September 1992)

\begin{abstract}
Brevibacterium linens can grow in media of relatively high osmotic strength (up to $3 \mathrm{M}-\mathrm{NaCl}$ ). Optimal growth in minimal medium occurred with either added $\mathrm{NaCl}(0 \cdot 5-1 \mathrm{M})$ or other osmolytes developing an equivalent osmotic pressure. Above $1 \mathrm{M}-\mathrm{NaCl}$ the growth rate slowed, but was enhanced by adding the osmoprotectant glycine betaine or its precursor choline $(1 \mathrm{mM})$ to the media. Neither soluble carbohydrates nor ninhydrin-reacting compounds accumulated during osmotic treatment. However, a Dragendorff-positive compound, together with $\mathrm{K}^{+}$ions, accumulated (7-fold) as a consequence of elevating the medium osmolality. Spectral characteristics of the purified compound were similar to those of synthesized 1,4,5,6-tetrahydro-2-methyl-4-pyrimidinecarboxylic acid (ectoine). In the absence of exogenously supplied osmoprotectants, a strict dependence between the intracellular ectoine content and the external salt concentration (up to $1 \mathrm{M}-\mathrm{NaCl}$ ) was observed. From 1 to $2 \mathrm{M}-\mathrm{NaCl}$, the ectoine content decreased, and this signalled decreased self-osmoprotection by this bacterium. Interestingly, at these salt concentrations, exogenous glycine betaine led to the greatest beneficial effect. Glycine betaine or choline added to the medium was actively taken up by the cells in an osmolality-dependent manner, and the resulting betaine accumulation caused a sharp decrease in intracellular ectoine content. Radiolabelling of ectoine occurred only when $\mathrm{L}-\left[\mathrm{U}-{ }^{14} \mathrm{C} \mid g l u t a m a t e\right.$ was used as a precursor; de novo synthesis was dependent on the external osmolality and was strongly inhibited by exogenously supplied glycine betaine. These results imply that ectoine may play a major role in counteracting the effects of osmotic stress in media of osmotic pressure equivalent to $₹ 1 \mathrm{M}-\mathrm{NaCl}$.
\end{abstract}

\section{Introduction}

The Gram-positive coryneform bacterium Brevibacterium linens is an important component of the surface microflora, and is involved in the ripening, of several cheeses (e.g. Livarot, Munster, Comté and Camembert). Many bacteria of this type are known for their ability to grow at relatively high salt concentrations; this suggests they could have a high osmoadjustment capacity, which would be necessary in order to maintain a positive cellular turgor.

Many investigations during the last decade have shown that only a small number of low-molecular-mass watersoluble molecules, together with $\mathrm{K}^{+}$, are important in enabling bacterial cells to counteract elevated osmotic pressure (Csonka, 1989; Csonka \& Hanson, 1991). Only a few amino acids and their methylated derivatives (betaines and thetins) have been found to be involved in cell osmoprotection (for reviews, see Imhoff, 1986;

* Author for correspondence. Tel. 99286140 ; fax 99286700 .

Abbreviation: L-DABA, L-diaminobutyric acid.
Csonka, 1989). The disaccharides sucrose, trehalose (Larsen et al., 1987; Dinnbier et al., 1988; Galinski \& Herzog, 1990; Welsh et al., 1991) and mannosucrose (Smith et al., 1990), and the dipeptide $\mathrm{N}$-acetylglutaminylglutamine amide (Smith \& Smith, 1989) have also been proposed to play a similar role.

Most studies of osmotic regulation have concentrated mainly on enterobacteria and a few other Gram-negative bacteria. These have established two steps in the protection process. The first is a transient accumulation of $\mathrm{K}^{+}$(Epstein \& Schultz, 1965; Dinnbier et al., 1988), together with a concomitant increase in cytoplasmic glutamate concentration (Measures, 1975; Botsford \& Lewis, 1990). The second response is the intracellular accumulation of one or several neutral compatible solutes: this is achieved either by de novo synthesis or by active transport from the external medium. Provided exogenously, the widely used osmoprotectants proline and glycine betaine are taken up via osmotically regulated transport systems, stimulating or restoring the growth of stressed cells (Dunlap \& Csonka, 1985; Perroud \& Le Rudulier, 1985; Bernard et al., 1986; Booth \& Higgins, 1990). 
Until recently, few reports have dealt with osmotic regulation in Gram-positive bacteria (Whatmore \& Reed, 1990; Jewell \& Kashket, 1991; Bae \& Miller, 1992; Graham \& Wilkinson, 1992). Among corynebacteria, in spite of their economical importance, only Brevibacterium lactofermentum (Kawahara et al., 1989, 1990) and B. ammoniagenes (Gouesbet et al., 1992) have been investigated. The work described here was undertaken to determine the osmoprotective strategy of $B$. linens. A potential intracellular osmoprotectant was isolated and identified by spectroscopic techniques as ectoine.

\section{Methods}

Media and growth conditions. Brevibacterium linens, strain CNRZ 211, was grown aerobically in LGS (lactate-glutamate-salts) minimal medium, containing, $\mathrm{l}^{-1}: 0.3 \mathrm{~g} \mathrm{KH}_{2} \mathrm{PO}_{4} ; 0.3 \mathrm{~g} \mathrm{Na}_{2} \mathrm{HPO}_{4}$; $0.1 \mathrm{~g} \mathrm{MgSO} 4.7 \mathrm{H}_{2} \mathrm{O} ; 0.05 \mathrm{~g} \mathrm{CaCl} 2.2 \mathrm{H}_{2} \mathrm{O} ; 10 \mathrm{mg} \mathrm{H}_{3} \mathrm{BO}_{3} ; 0.5 \mathrm{mg}$ $\mathrm{ZnSO}_{4} .7 \mathrm{H}_{2} \mathrm{O} ; 0.5 \mathrm{mg} \mathrm{CuSO}_{4} .5 \mathrm{H}_{2} \mathrm{O} ; 0.5 \mathrm{mg} \mathrm{MnCl}_{2} .4 \mathrm{H}_{2} \mathrm{O} ; 0.1 \mathrm{mg}$ $\mathrm{Na}_{2} \mathrm{MoO}_{4} .2 \mathrm{H}_{2} \mathrm{O} ; 1 \mathrm{mg}$ Fe-EDTA; $0.2 \mathrm{mg}$ biotin; $10 \mathrm{~mm}$-sodium lactate and $10 \mathrm{~mm}$-sodium glutamate were the $\mathrm{C}$ and $\mathrm{N}$ sources respectively. The $\mathrm{pH}$ was adjusted to 7.0 after autoclaving. Pre-cultures were grown on LB medium (Miller, 1972) and used to inoculate LGS at $2 \%(\mathrm{v} / \mathrm{v})$. Both cultures were aerated by rotary shaking (150 r.p.m.) at $28{ }^{\circ} \mathrm{C}$. Growth was monitored by measuring the optical density at $570 \mathrm{~nm}$ using a Beckman DU 64 spectrophotometer.

Minimal media with elevated osmotic strength were prepared by adding $\mathrm{NaCl}, \mathrm{KCl}$ or the non-electrolytes sucrose or glycerol at appropriate concentrations; if required, osmoprotectants were supplied at a final concentration of $1 \mathrm{~mm}$. The osmotic pressure of each medium was measured by freezing-point determination. The dry cell weight was estimated from washed cells; duplicate subsamples of fresh cell slurry were dried, in centrifuge tubes, for at least $24 \mathrm{~h}$ at $80^{\circ} \mathrm{C}$, until constant weight was attained; dry weights differed by less than $2 \%$. For physiological studies, cells in the exponential growth phase were harvested by centrifugation and maintained at $4{ }^{\circ} \mathrm{C}$ until use.

Extraction of cellular solutes. Cells growing exponentially were collected by centrifugation $(5000 \mathrm{~g}, 10 \mathrm{~min})$, washed twice with isotonic growth medium and extracted twice in $80 \%(\mathrm{v} / \mathrm{v})$ ethanol, at room temperature, under vigorous magnetic stirring. After centrifugation the supernatants were pooled and evaporated to dryness under reduced pressure at $40^{\circ} \mathrm{C}$. The dried residue was dissolved in a minimal volume of distilled water and stored in the freezer at $-20^{\circ} \mathrm{C}$ until use for amino acid, sugar and mineral determinations. The pellet, which comprised the whole insoluble fraction, was oven-dried at $80^{\circ} \mathrm{C} . \mathrm{K}^{+}$ was extracted from cells grown in the same conditions and harvested by centrifugation; samples were then rinsed thoroughly with isotonic sorbitol or $\mathrm{NaCl}$, to remove the extracellular $\mathrm{K}^{+}$from the cell wall and the culture medium. Extraction was done using $0 \cdot 1 \mathrm{M}-\mathrm{HCl}$ for $24 \mathrm{~h}$ at room temperature.

Chromatographic and electrophoretic analysis. The ethanol-soluble fraction was used directly or after partial purification by passage through a cation-exchange column $(20 \times 1 \mathrm{~cm})$ of Bio-Rad AG $50 \times 8$, $\mathrm{H}^{+}$form. Amino acids and derivative compounds were eluted with $2 \mathrm{M}-$ $\mathrm{NH}_{4} \mathrm{OH}$ and the resulting solution was evaporated to dryness. The residue was dissolved in $1 \mathrm{ml}$ of distilled water and analysed as described previously (Gouesbet et al., 1992). Amino acids were detected by spraying a solution of ninhydrin $(0.4 \%, w / v)$ in $n$-butanol onto chromatograms followed by heating at $80^{\circ} \mathrm{C}$. Onium compounds were detected as orange-coloured spots resulting from spraying at room temperature with Dragendorff reagent $(0 \cdot 4 \%, w / v$, bismuth carbonate and $1.5 \%, \mathrm{w} / \mathrm{v}$, potassium iodide dissolved in $1 \mathrm{M}-\mathrm{HCl}$ )

Intracellular solute concentrations. Total amino acids were measured as described by Yemm \& Cocking (1955), using L-leucine as a standard. Since the imino acid proline could not be detected by this procedure, it was determined using the method of Troll \& Lindsley (1955). Total sugars were determined by the method of Roe (1955); a solution of $\mathbf{D}(+)$-glucose was used as a standard. Since the presence of a Dragendorff-positive compound was revealed by chromatography techniques, an attempt to quantify this compound was undertaken using a procedure adapted from Storey \& Wyn Jones (1977) for betaine determination. Briefly, $50 \mu \mathrm{l} 2 \mathrm{M}-\mathrm{HCl}$, followed by $150 \mu \mathrm{l} \mathrm{M}-\mathrm{HCl}$ and $100 \mu \mathrm{l}$ of $\mathrm{I}_{2} / \mathrm{KI}$ solution were added to $50 \mu \mathrm{l}$ of ethanolic extract. The mixture was stored at $4{ }^{\circ} \mathrm{C}$ for $90 \mathrm{~min}$ and then added to $100 \mu$ of cold distilled water and $5 \mathrm{ml}$ of cold dichloroethane. After $15 \mathrm{~s}$ of vigorous shaking, the organic and aqueous phases were separated by centrifugation at $3000 \mathrm{~g}$ for $10 \mathrm{~min}$. The lower organic phase was monitored in a spectrophotometer at $368 \mathrm{~nm} . \mathrm{K}^{+}$was assayed using a flame photometer. Quantification was done by referring to standard solutions of $\mathrm{KCl}(0.25$ to $1 \mathrm{~mm})$. All determinations were repeated at least once, with less than $5 \%$ error.

Isolation, purification, and characterization of a Dragendorff-positive intracellular solute. Intracellular solutes were extracted from bacterial cells, grown in a fermenter ( 8 litre) at $28^{\circ} \mathrm{C}$ in LGS medium. To increase the growth rate, the osmotic pressure of the media was raised by addition of $\mathrm{NaCl}$ ( $1 \mathrm{M}$ final concentration). The cells were harvested by centrifugation at the late exponential phase of growth and extracted twice with $80 \%(\mathrm{v} / \mathrm{v})$ ethanol.

The ethanol-soluble fraction was evaporated to dryness at $40{ }^{\circ} \mathrm{C}$ and the residue resuspended in a minimal volume of methanol. After centrifugation, the supernatant $(10 \mathrm{ml})$ was supplemented with $2 \mathrm{~g}$ ninhydrin and incubated in a boiling water bath for $15 \mathrm{~min}$ to destroy amino acids and other related compounds reacting with ninhydrin. The solid debris was decanted and the whole clear supernatant passed through a cation exchange resin (Bio- $\mathrm{Rad} \mathrm{AG} 50 \times 8, \mathrm{H}^{+}$form). The column was washed successively with ethanol and water, and eluted with $2 \mathrm{M}-\mathrm{NH}_{4} \mathrm{OH}$.

The resulting solution was dried under vacuum and analysed by paper chromatography and electrophoresis (Whatman 3MM paper). As expected after ninhydrin treatment, no spot was detected by ninhydrin spraying and heating at $80^{\circ} \mathrm{C}$. However, spraying with Dragendorff reagent resulted in the development of an orange-coloured spot at room temperature, $10-15 \mathrm{~h}$ after spraying. This response to iodine is widely used for colorimetric detection of most onium (either $\mathrm{N}^{+}$or $\mathrm{S}^{+}$) compounds. The extract was subjected to preparative paper chromatography run in phenolic solvent; the Dragendorff-positive compound was eluted with $2 \mathrm{~mm}-\mathrm{HCl}$ and further purified by electrophoresis. It was crystallized by slowly cooling a hot saturated aqueous solution or by adding diethyl ether to an ethanolic solution of its hydrochloride. The crystallized material was analysed by NMR. mass spectrometry and IR spectroscopy.

The ${ }^{13} \mathrm{C}$ NMR, ${ }^{1} \mathrm{H}$ NMR and mass spectra were recorded as described previously (Gouesbet et al., 1992). IR analysis was done on a purified sample in Nujol (Aldrich). In vivo ${ }^{1} \mathrm{H}$ NMR was done using bacterial cells cultivated in minimal medium $(200 \mathrm{ml})$ without or with added $1 \mathrm{M}-\mathrm{NaCl}$ (in the presence or absence of $1 \mathrm{~mm}$-choline) and harvested at late exponential growth phase. The partially dehydrated pellet was resuspended in $\mathrm{D}_{2} \mathrm{O}$ or in a solution of $1 \mathrm{M}-\mathrm{NaCl}$ in $\mathrm{D}_{2} \mathrm{O}$; $0.6 \mathrm{ml}$ of the suspension was poured into the NMR tube; to avoid interference, no reference was added to the suspension. Acquisition of NMR data was within less than $20 \mathrm{~min}$

Chemical synthesis and degradation of ectoine. Chemical synthesis of ectoine was undertaken by thermal cyclization of $\gamma$-N-acetyl- 
diaminobutyric acid, itself synthesized by acetylation of L-diaminobutyric acid (L-DABA; Sigma) using p-nitrophenyl acetate (Leclerc \& Benoiton, 1968) and characterized by ${ }^{1} \mathrm{H},{ }^{13} \mathrm{C}$ NMR spectroscopy and mass spectrometry. Refluxing $N$-acetyl-DABA in $\mathrm{n}$-butanol in the presence of an equimolar amount of triethylamine for $48 \mathrm{~h}$ gave a mixture of ectoine $(60 \%)$ and $N$-acetyl-DABA $(40 \%)$ as estimated by ${ }^{1} \mathrm{H}$ NMR. The same cyclization was observed when a mixture of butanol and xylene $(30: 70, \mathrm{v} / \mathrm{v})$ was refluxed in the presence of $p$ toluenesulphonic acid $(20 \%, \mathrm{w} / \mathrm{v})$ for $48 \mathrm{~h}$. In this case, the relative proportions were $44 \%$ ectoine and $56 \% \mathrm{~N}$-acetyl-DABA. Chemical degradation was done in the presence of $2.5 \mathrm{M}-\mathrm{NaOH}$ at $100{ }^{\circ} \mathrm{C}$ for $3 \mathrm{~h}$ in sealed vials, as described by Inbar \& Lapidot (1988).

Radiolabel assays. Transport and metabolic assays were done with $\left[\right.$ methyl $\left.-{ }^{14} \mathrm{C}\right]$ glycine betaine. This molecule was prepared from [methyl${ }^{14} \mathrm{C}$ ]choline chloride $\left(2.07 \mathrm{GBq} \mathrm{mmol}^{-1}\right.$; CEA, France) as described by lkuta et al. (1977). Radioactive choline was enzymically oxidized by choline oxidase from Alcaligenes sp. (Sigma), and $\left[{ }^{14} \mathrm{C}\right]$ glycine betaine was purified as described by Perroud \& Le Rudulier (1985).

Transport assays were done using the procedure of Gouesbet $e t$ al. (1992). In all experiments, the total concentration of glycine betaine or choline in the transport assays was adjusted so that no more than $20 \%$ of the substrate was taken up during the course of the reaction. For metabolic investigations, $\left[1,2-{ }^{14} \mathrm{C}\right]$ glycine betaine was preferred to the methyl-labelled molecule. It was prepared from $\left[1,2-{ }^{14} \mathrm{C}\right]$ choline (1.6 GBq $\mathrm{mmol}^{-1}$ ).

$\mathrm{L}-\left[\mathrm{U}-{ }^{14} \mathrm{C}\right]$ Glutamate $\left(9.94 \mathrm{MBq} \mathrm{mmol}^{-1}\right.$; Amersham) was used as a precursor of endogenous osmoprotectants; typical labelling assays were done using $20 \mu \mathrm{l}$ of the radioactive amino acid to $0.5 \mathrm{ml}$ of cell suspension in LGS medium without or with added $\mathrm{NaCl}$. Subsamples $(0.1 \mathrm{ml})$ were taken at intervals and filtered; filters were either counted directly for radioactivity or extracted in $80 \%(\mathrm{v} / \mathrm{v})$ ethanol to detect labelled metabolites. Preparative in vivo osmoprotectant labelling was determined using growing cells, in LGS medium supplemented with $1 \%(\mathrm{w} / \mathrm{v})$ Bacto-tryptone, at $\mathrm{OD}_{570}=1$. The cells were supplied with radiolabelled substrate $(18.5 \mu \mathrm{M})$ and incubated for $5-6 \mathrm{~h}$ at $28^{\circ} \mathrm{C}$. After harvesting by centrifugation, the pelleted cells were extracted in $80 \%(\mathrm{v} / \mathrm{v})$ ethanol and ectoine was purified as described.

Cell volume determination. Cell volume was measured by the method of Stock et al. (1977) using the permeating solvent ${ }^{3} \mathrm{H}_{2} \mathrm{O}(400 \mathrm{MBq}$ $\left.\mathrm{ml}^{-1} ; \mathrm{CEA}\right)$ and the non-permeating solute inulin-hydroxy $\left[{ }^{14} \mathrm{C}\right] \mathrm{methyl}$ $\left(156.5 \mathrm{kBq} \mathrm{mg}^{-1}\right.$; CEA). These compounds were added to cells grown at different osmolalities. Cells in exponential growth phase were concentrated 10 times from the corresponding culture medium. Samples of $0.5 \mathrm{ml}$ of the concentrated cells were added in parallel, either with tritiated water or with ${ }^{14} \mathrm{C}$-labelled inulin, and incubated for $30 \mathrm{~min}$ at room temperature. Following centrifugation at $13000 \mathrm{~g}$ for $5 \mathrm{~min}$, the radioactivity in $100 \mu \mathrm{l}$ of the supernatant and the whole pellet was determined. The cytoplasmic volume was calculated from triplicate assays with less than $5 \%$ error and expressed in $\mu \mathrm{l}(\mathrm{ml} \text { suspension })^{-1}$ at $\mathrm{OD}_{570}=1$.

\section{Results and Discussion}

\section{Effect of increased osmolality on bacterial growth}

To analyse the response to increased medium osmolality, the bacteria were grown in LGS medium supplemented with $0 \cdot 2-3 \cdot 0 \mathrm{M}-\mathrm{NaCl}$ (Fig. 1; Table 1). The osmotic pressure developed by these culture media ranged from $0.06(0 \mathrm{M}-\mathrm{NaCl})$ to approximately $5.40 \mathrm{osmol}\left(\mathrm{kg} \mathrm{H}_{2} \mathrm{O}\right)^{-1}$ $(3 \mathrm{M}-\mathrm{NaCl})$. The maximum growth rate was in media containing between 0.5 and $1 \mathrm{M}-\mathrm{NaCl}$ (generation time: 8-9 h). Growth was slow in basal medium without added $\mathrm{NaCl}(26 \mathrm{~h})$ and was inhibited above $1.0 \mathrm{M}-\mathrm{NaCl}$ with a

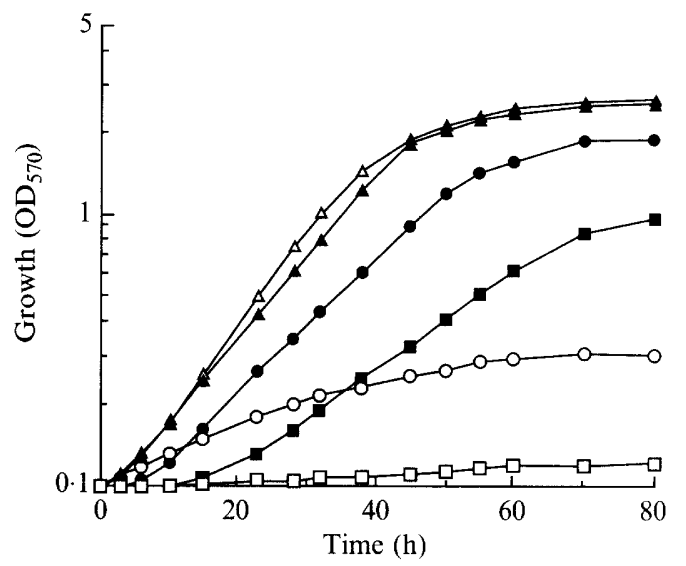

Fig. 1. Effect of $\mathrm{NaCl}$ concentration on growth of $B$. linens. Cells were grown aerobically at $28^{\circ} \mathrm{C}$ in LGS medium. $\mathrm{O}$, Without added $\mathrm{NaCl}$ : $\boldsymbol{\Delta}, 0.2 \mathrm{M}-\mathrm{NaCl} ; \triangle, 0.5 \mathrm{M}-\mathrm{NaCl} ; \boldsymbol{O}, 1 \mathrm{M}-\mathrm{NaCl} ; \mathbf{\square}, 2 \mathrm{M}-\mathrm{NaCl} ; \square, 3 \mathrm{M}-$ $\mathrm{NaCl}$.

Table 1. Growth of B. linens in media of various osmolalities, without or with added $1 \mathrm{~mm}$-glycine betaine

Dry biomass $\left(\mathrm{mg} \mathrm{l}^{-1}\right)$ was determined after $80 \mathrm{~h}$ of culture. Values are means of duplicate determinations. ND, Not determined.

\begin{tabular}{|c|c|c|c|c|c|}
\hline \multirow[b]{2}{*}{$\begin{array}{l}\mathrm{NaCl} \text { concn } \\
\text { in medium } \\
(\mathrm{M})\end{array}$} & \multirow[b]{2}{*}{$\begin{array}{c}\text { Osmolality } \\
{\left[\text { osmol }\left(\mathrm{kg} \mathrm{H}_{2} \mathrm{O}\right)^{-1}\right]}\end{array}$} & \multicolumn{2}{|c|}{ Without GB } & \multicolumn{2}{|c|}{ With GB } \\
\hline & & $\begin{array}{c}\text { Dry } \\
\text { biomass } \\
(\mathrm{mg})\end{array}$ & $\begin{array}{l}\text { Generation } \\
\text { time } \\
(\mathrm{h})\end{array}$ & $\begin{array}{c}\text { Dry } \\
\text { biomass } \\
\text { (mg) }\end{array}$ & $\begin{array}{l}\text { Generation } \\
\text { time } \\
\text { (h) }\end{array}$ \\
\hline 0 & 0.06 & 83 & 26 & 80 & ND \\
\hline $0 \cdot 5$ & 0.90 & 825 & 8 & 825 & ND \\
\hline $1 \cdot 0$ & 1.85 & 918 & 9 & 1050 & 7 \\
\hline 1.5 & $2 \cdot 72$ & 704 & 12 & 1001 & $9 \cdot 5$ \\
\hline 2.0 & $3 \cdot 70$ & 339 & 17 & 836 & $10 \cdot 5$ \\
\hline $2 \cdot 5$ & $4 \cdot 46$ & 76 & ND & 209 & 22 \\
\hline $3 \cdot 0$ & $5 \cdot 45$ & 46 & ND & 68 & ND \\
\hline
\end{tabular}


generation time of $12 \mathrm{~h}$ and $17 \mathrm{~h}$ for media containing 1.5 and $2 \mathrm{M}-\mathrm{NaCl}$ respectively. At $3 \mathrm{M}-\mathrm{NaCl}$, growth was poor and the cell yield was reduced by $95 \%$ compared to cells grown in $1 \mathrm{M}-\mathrm{NaCl}$; in parallel, the lag phase increased $(2 \mathrm{~h}$ at $0.5 \mathrm{M}-$ and $15 \mathrm{~h}$ at $2 \mathrm{M}-\mathrm{NaCl})$. Dry weight determination (Table 1) confirmed that poor growth occurred in minimal medium deprived of $\mathrm{NaCl}$ $(79.5 \mathrm{mg}$ dry wt per litre of culture). In optimal conditions the yield was 825 and $918 \mathrm{mg}$ at 0.5 and $1 \mathrm{M}$ $\mathrm{NaCl}$ respectively. The yield decreased at high $\mathrm{NaCl}$ concentrations. Replacement of $\mathrm{NaCl}$ by other electrolytes such as $\mathrm{KCl}$ and $\mathrm{Na}_{2} \mathrm{SO}_{4}$, or the non-electrolyte sucrose, at similar osmolalities, did not induce significant changes in the growth pattern (data not shown), while addition of the permeant solute glycerol allowed only poor growth. Cell volume changes were observed that were dependent on the culture medium osmotic strength. The cell volumes were $0.83 \mu \mathrm{l}$ per $\mathrm{ml}$ of cell suspension $\left(\mathrm{OD}_{570}=1\right)$ in $0 \mathrm{M}-\mathrm{NaCl}, 0.66 \mu \mathrm{l}$ at $0.5 \mathrm{M}-$, $0.49 \mu \mathrm{l}$ at $1 \mathrm{M}-$ and $0.46 \mu \mathrm{l}$ at $2 \mathrm{M}-\mathrm{NaCl}$.

\section{Effect of the osmoprotectant glycine betaine on growth}

Glycine betaine was added to the culture medium at a final concentration of $1 \mathrm{~mm}$, with or without $0.5,1,1 \cdot 5$, $2,2.5$ and $3 \mathrm{M}-\mathrm{NaCl}$. From 0 to $1 \mathrm{M}-\mathrm{NaCl}$, no significant change was observed either in the dry cell biomass (Table 1) or in the growth pattern. Above this concentration, glycine betaine shortened both the lag phase and the generation time, and raised the growth yield; the response was maximal at $2.5 \mathrm{M}-\mathrm{NaCl}(2.8$-fold increase in dry cell wt). Even at $3 \mathrm{M}-\mathrm{NaCl}$, a small alleviation of salt stress occurred when betaine was present. Addition of choline ( $1 \mathrm{~mm}$ ) under elevated osmotic conditions led to the same results as with glycine betaine. Chromatographic analysis of cell extracts from these experiments showed a complete conversion of choline to betaine. Furthermore, $\left[{ }^{14} \mathrm{C}\right]$ choline and $\left[{ }^{14} \mathrm{C}\right]$ betaine supplied to cell suspension with and without added 0.5 and $1 \mathrm{M}-\mathrm{NaCl}$ (data not shown) showed that both molecules were actively taken up and accumulated intracellularly as glycine betaine in an osmo-dependent manner; no further metabolism of the betaine was found. Thus, unlike several other bacteria showing growth restoration in the presence of betaine or its precursor choline (Csonka, 1989), B. linens showed the beneficial effect of osmoprotectants only under high osmotic stress.

\section{Intracellular accumulated solute detection, purification and characterization}

Since $B$. linens exhibits a maximum growth rate at relatively high osmotic strength, it can be inferred that it should accumulate one or more intracellular solutes to
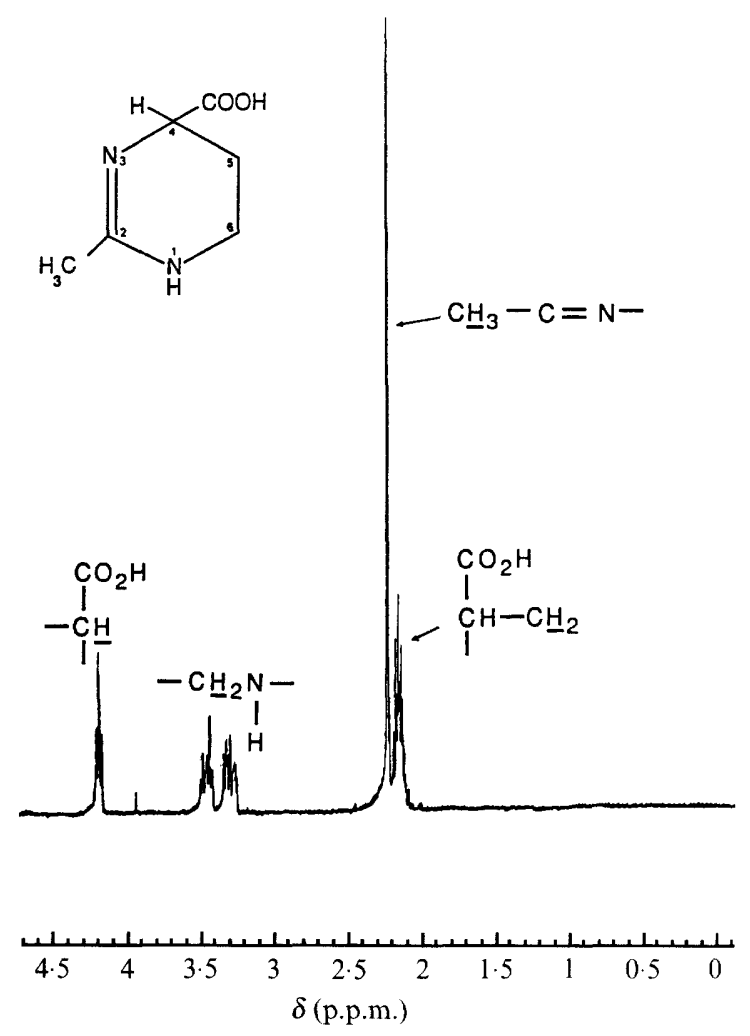

Fig. 2. ${ }^{1}$ H NMR spectrum of ectoine isolated and purified from $B$. linens cells growing exponentially in LGS medium with added $1 \mathrm{M}-\mathrm{NaCl}$.

combat increased osmotic strength. Chromatographic analyses demonstrated a Dragendorff-positive compound, the concentration of which increased with the osmotic strength. Paper chromatography showed that this compound had $R_{F}$ values of 0.42 and 0.75 , respectively, in butanol and phenol solvents. Electrophoretic separation of the compound, relative to that of choline, had an $R_{F}$ of 0.51 .

As the compound was relatively abundant in ethanolsoluble extracts, isolation and subsequent purification were undertaken. After removal of amino compounds and elimination of neutral and acidic molecules from the crude extract, $600-700 \mathrm{mg}$ of purified product were obtained from an 8 litre fermenter culture, grown in the presence of $1 \mathrm{M}-\mathrm{NaCl}$. When required, further purification was done using preparative chromatography (phenol solvent) combined with paper electrophoresis.

The crystallized compound was analysed by NMR, mass spectrometry and IR spectroscopy and a product of its chemical degradation was identified. Both ${ }^{1} \mathrm{H}$ (Fig. 2), and ${ }^{13} \mathrm{C}$ NMR spectra were obtained from about $10 \mathrm{mg}$ of the compound dissolved in $\mathrm{D}_{2} \mathrm{O}$; chemical shifts were expressed in p.p.m. downfield from DSS $(2,2-$ dimethyl-2-silapentane-5-sulphonate). ${ }^{1} \mathrm{H}: 2 \cdot 21(s, 3 \mathrm{H}$, $\left.\mathrm{CH}_{3}-\mathrm{C}=\mathrm{N}\right) ; 2.13\left(m, 2 \mathrm{H},-\mathrm{CH}_{2}-\mathrm{CH}-\mathrm{N}\right) ; 3.38(m, 2 \mathrm{H}$, 
$\left.\mathrm{NH}-\mathrm{CH}_{2}-\right) ; 4.08\left(t, 1 \mathrm{H}, \mathrm{N}-\mathrm{CH}-\mathrm{CO}_{2} \mathrm{H}\right) .{ }^{13} \mathrm{C}: 18.7(q$, $\left.\mathrm{CH}_{3}\right) ; 22.0\left(t, \mathrm{CH}_{2}-\mathrm{CH}-\mathrm{N},{ }^{1} J \mathrm{CH}=130 \mathrm{~Hz}\right) ; 37.9(t$, $\left.\mathrm{NH}-\mathrm{CH}_{2}-,{ }^{1} J \mathrm{CH}=145 \mathrm{~Hz}\right) ; 53.8\left(d, \underline{\mathrm{C}} \mathrm{H}, \mathrm{CO}_{2} \mathrm{H}\right) ; 161.2$ $(s, \mathrm{C}=\mathrm{N}) ; 176 \cdot 8(s, \mathrm{C}=\mathrm{O})$.

In the IR spectrum (in Nujol), vibrations were observed at $3000-2850 \mathrm{~cm}^{-1}(v \mathrm{OH})$ and $1680-1600 \mathrm{~cm}^{-1}$ $(v \mathrm{C}=\mathrm{N})$. The mass spectrum gave a molecular peak $M^{+}$. $=142$, corresponding to $\mathrm{C}_{6} \mathrm{H}_{10} \mathrm{~N}_{2} \mathrm{O}_{2}$, and a base peak resulting from $\alpha$-cleavage $\left(M^{+}-\mathrm{CO}_{2} \mathrm{H}\right)=97$; calculated mass $=142 \cdot 07422$, found $=142 \cdot 0742$.

These data imply that the compound is the diazine derivative 1,4,5,6-tetrahydro-2-methyl-4-pyrimidinecarboxylic acid, previously isolated from the halophilic phototrophic bacterium Ectothiorhodospira halochloris (Galinski et al., 1985) and called ectoine.

The identification of this cyclic imino acid was confirmed by comparison with two authentic samples, one supplied by Dr E. A. Galinski and the other synthesized in the laboratory (see Methods). Moreover, chemical degradation, in the presence of $2.5 \mathrm{M}-\mathrm{NaOH}$ at $110^{\circ} \mathrm{C}$ led to the complete transformation of the purified ectoine, giving only one ninhydrin-positive compound identified as diaminobutyric acid by co-chromatography.

\section{In vivo ${ }^{1} H$ NMR detection of ectoine}

Since the ${ }^{1} \mathrm{H}$ NMR spectrum from the purified ectoine showed specific signals, a non-destructive approach was used to detect the intracellular accumulated solute. Fig. 3 shows typical ${ }^{1} \mathrm{H}$ NMR spectra from bacterial cells cultivated in minimal medium without $\mathrm{NaCl}$, with added $1 \mathrm{M}-\mathrm{NaCl}$, and with added $1 \mathrm{M}-\mathrm{NaCl}$ and $1 \mathrm{~mm}$-choline. A subsample of the suspension in $1 \mathrm{M}-\mathrm{NaCl}$ was supplemented with authentic ectoine before the start of analysis, as a control.

In minimal medium, without $\mathrm{NaCl}$, the cell suspension showed no peak identifiable as ectoine; in particular, the principal specific peak (a singlet signal) at 2.21 p.p.m. from $-\mathrm{CH}_{3}$ was absent. The large unknown peaks (X), might originate from protons belonging to the cell envelope or to intracellular macromolecules.

In the presence of $1 \mathrm{M}-\mathrm{NaCl}$, the broad signals were minimal and the main peaks from ectoine were apparent. This was confirmed with the addition of pure ectoine to the cell suspension. Cultivating cells in the presence of choline at elevated osmolality led to a decrease in ectoine signals; interestingly, new signals, attributable to proton resonances from the methyl and methylene groups of glycine betaine, were predominant. These data, obtained in less than $20 \mathrm{~min}$ of analysis, are in agreement with those stated previously to be characteristic of the complete oxidation of choline to the corresponding betaine. The spectral data were confirmed by chromatographic analysis.

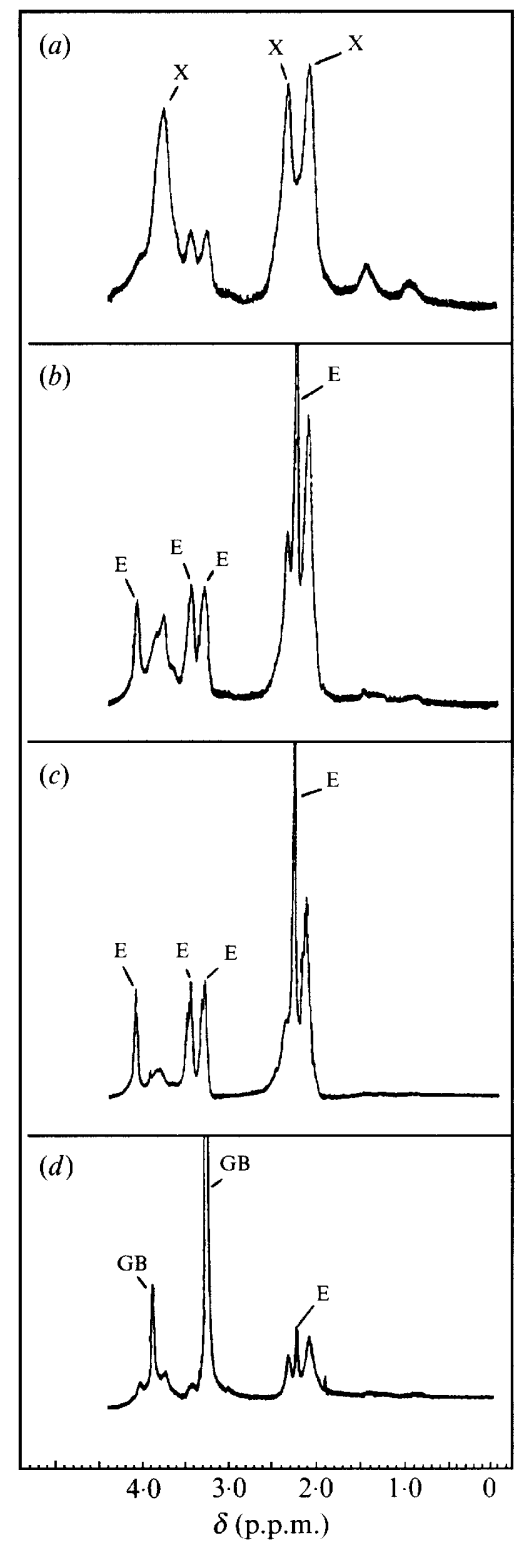

Fig. 3. In vivo ${ }^{1} \mathrm{H}$ NMR spectra of $B$. linens. Cell suspensions were concentrated from exponentially growing cultures in LGS medium with or without added $1 \mathrm{M}-\mathrm{NaCl}$, supplemented or not with $1 \mathrm{M}$ choline. After centrifugation, the pellet was rinsed with the corresponding culture medium lacking carbon and nitrogen sources and resuspended in $\mathrm{D}_{2} \mathrm{O}$ with or without added $1 \mathrm{M}-\mathrm{NaCl} ; 0.6 \mathrm{ml}$ samples were poured into the NMR tubes. (a) Cells grown without $\mathrm{NaCl} ;(b)$ cells grown with $1 \mathrm{M}-\mathrm{NaCl} ;(c)$ cells grown with $1 \mathrm{M}-\mathrm{NaCl}$ and supplemented with pure ectoine at the start of analysis; $(d)$ cells grown with $1 \mathrm{M}-\mathrm{NaCl}$ in the presence of $1 \mathrm{~mm}$-choline. E, ectoine; GB, glycine betaine; $\mathrm{X}$, unknown peaks (see text)

\section{Intracellular solutes}

Total ninhydrin-reacting amino acids, anthrone-reacting sugars, ectoine and $\mathrm{K}^{+}$were determined in extracts from cells grown in $0,0.2,0.5,1.0,1.5$ and $2.0 \mathrm{M}-\mathrm{NaCl}$ (Table 2). Proline, an imino acid that commonly accumulates in cells subjected to osmotic stress, was never found in 
Table 2. Effects of increasing medium osmolality on the content of intracellular solutes

Values are means of duplicate assays and are expressed as nmol $(\mathrm{mg} \text { dry cell wt })^{-1}$. ND, Not determined.

\begin{tabular}{ccccc}
\hline \hline $\begin{array}{c}\mathrm{NaCl} \text { concn } \\
\text { in medium } \\
(\mathrm{M})\end{array}$ & $\begin{array}{c}\text { Amino acids } \\
\text { (ninhydrin-reacting) }\end{array}$ & $\begin{array}{c}\text { Sugars } \\
\text { (total) }\end{array}$ & Ectoine & $\mathrm{K}^{+}$ \\
\hline 0 & 46 & 67 & 209 & 267 \\
$0 \cdot 2$ & 87 & $\mathrm{ND}$ & 945 & 485 \\
0.5 & 104 & 93 & 1197 & 632 \\
$1 \cdot 0$ & 127 & 82 & 1448 & 765 \\
1.5 & 116 & 61 & 1239 & 770 \\
$2 \cdot 0$ & 75 & 69 & 461 & 487 \\
\hline \hline
\end{tabular}

significant amounts. Total soluble carbohydrates did not exceed $93 \mathrm{nmol}\left(\mathrm{mg}\right.$ dry wt) ${ }^{-1}$, and did not correlate with changes in medium osmolality. In contrast, other solutes were sensitive to changes in salt concentration (Table 2). Total ninhydrin-reacting amino acids levels reached a maximum of $127 \mathrm{nmol}$ at $1 \mathrm{M}-\mathrm{NaCl}$ and appeared dependent on medium osmolality, at least up to this salt concentration. Chromatographic analysis showed that glutamate and glutamine are the major components of the soluble amino acid pool. $\mathrm{K}^{+}$levels were relatively high, and increased as the salt concentration was increased from 0 to $1.5 \mathrm{M}-\mathrm{NaCl} . \mathrm{K}^{+}$represented, in all cases, more than $30 \%$ of the total determined soluble compounds and was $46 \%$ of the total solutes at $2 \mathrm{M}$ $\mathrm{NaCl}$. There are many reports of Gram-negative and Gram-positive bacteria increasing the cellular $\mathrm{K}^{+}$content in media of raised osmolality. Intracellular $\mathrm{K}^{+}$contents from 0.5 to $1 \mu \mathrm{mol}$ (mg dry wt) $)^{-1}$ are very common. $B$. linens accumulates up to $0.77 \mu \mathrm{mol} \mathrm{K}^{+}$at $1.5 \mathrm{M}-\mathrm{NaCl}$. Since a notable percentage of the $\mathrm{K}^{+}$content is generally considered as taking part in electro-neutralization of polyanionic insoluble macromolecules (Cayley et al., 1991), it is difficult to determine the osmotically active intracellular level. Nevertheless, one can expect that at least one-half of the total may participate in osmotic balancing.

Ectoine was by far the major intracellular solute; its level was dramatically enhanced when osmotic stress was applied to the cells. It represented around $60 \%$ of the solute pool at $0.5,1$ and $1.5 \mathrm{M}-\mathrm{NaCl}$ and more than $30 \%$ in all other conditions. It reached a maximum of $1448 \mathrm{nmol}$ (mg dry wt) $)^{-1}$ at $1 \mathrm{M}-\mathrm{NaCl}$ (7-fold increase compared to no $\mathrm{NaCl}$ ), and accounted for more than $20 \%$ of the dry biomass. With respect to the total amino acid pool, this heterocyclic non-protein imino acid constituted more than $80 \%$ of the total at all osmotic strengths of the culture media. Even in the absence of added $\mathrm{NaCl}$, its level was still 5 times that of the aggregate of all the other amino acids. By determining the intracellular volume (inaccessible to ${ }^{14} \mathrm{C}$-labelled inulin), it was possible to calculate its approximate concentration. At $1 \mathrm{M}-\mathrm{NaCl}$ the cell volume was $1.31 \mu \mathrm{l}$ (mg dry cell wt) ${ }^{-1}$ and the corresponding ectoine concentration was at least $1.1 \mathrm{M}$; such a solution could develop an osmolality equivalent to that of $0.85 \mathrm{M}-\mathrm{NaCl}$ (osmometer measurement). This osmolality is not sufficient to equilibrate the external osmotic pressure caused by $1 \mathrm{M}-\mathrm{NaCl}$. Hence other cytoplasmic solutes, including other amino acids, sugars and $\mathrm{K}^{+}$may be necessary to complete the osmotic balance. These compounds have to equilibrate the cell osmolality and to contribute to turgor pressure maintenance, which is known to reach about $2-2.5 \mathrm{MPa}$ (corresponding to $0.4-0.5 \mathrm{M}-\mathrm{NaCl}$ ) in most Gram-positive bacteria investigated so far (Whatmore \& Reed, 1990). When glycine betaine (1 mM) was added to medium containing $1 \mathrm{M}-\mathrm{NaCl}$ the concentration of ectoine decreased to that found in medium without added $\mathrm{NaCl}$; an identical response was observed for additions of choline, proline, trehalose, taurine, $\beta$ dimethylsulphoniopropionate, carnitine and $\gamma$-butyrobetaine ( $1 \mathrm{~mm}$ each).

Increasing the osmotic constraint causes $B$. linens to severely lower its ectoine content (Table 2) and, thereby, inhibits growth; thus, at $2 \mathrm{M}-\mathrm{NaCl}$, on a determined cell volume of $1.22 \mu \mathrm{l}(\mathrm{mg} \text { dry wt })^{-1}$, the intracellular concentration of ectoine was only $0.38 \mathrm{M}$, which represents only $10 \%$ of the external osmotic pressure. As shown above, glycine betaine can alleviate this growth inhibition and accumulate intracellularly; a maximum accumulation was observed at 1.5 and $2 \mathrm{M}-\mathrm{NaCl}[2.2 \mu \mathrm{mol}$ (mg dry wt) $)^{-1}$. This accounts for up to $26 \%$ of the dry biomass and reaches a cellular concentration as high as $1.8 \mathrm{M}$. Even at lower medium osmolalities, glycine betaine and a few other osmoprotectants have been shown to be efficient in maintaining osmotic equilibrium; all were readily accumulated and strikingly inhibited ectoine biosynthesis. Several bacteria show a similar behaviour, apparently preferring the inexpensive uptake of an exogenous protectant to the higher energy-requiring biosynthesis of an endogenous compatible solute.

Ectoine was first characterized in the extreme halophilic bacterium Ectothiorhodospira halochloris (Galinski et al., 1985) and a few Halomonadaceae (Wohlfarth et al., 1990), as well as in the moderately halophilic bacteria Ba1 and Vibrio costicola (Regev et al., 1990). Its intracellular concentration has been shown to increase with medium osmolality, but to no more than $0.4 \mathrm{M}$ in $E$. halochloris (Galinski et al., 1985), and $0 \cdot 1 \mathrm{M}$ and $0 \cdot 2 \mathrm{M}$ at $1 \mathrm{M}-$ and $2 \mathrm{M}-\mathrm{NaCl}$, respectively, in the bacterium Bal (Regev et al., 1990). Only Halomonas elongata (Wohlfarth et al., 1990) displays a much higher level of ectoine [1.83 $\left.\mu \mathrm{mol}(\mathrm{mg} \text { dry wt })^{-1}\right]$, but at a more elevated salt concentration $(3.4 \mathrm{M}-\mathrm{NaCl})$. Two other imino acids have 
been found to accumulate in response to elevated osmotic conditions in corynebacteria; Kawahara et al. (1989) showed that there was a direct correlation between proline accumulation and medium osmolality in Brevibacterium lactofermentum; Gouesbet et al. (1992) showed, in Brevibacterium ammoniagenes, a significant increase in pipecolic acid as a consequence of enhanced medium osmolality. In both bacteria, the maximal level attained by the accumulated imino acid did not exceed 304 and $130 \mathrm{nmol}$ (mg dry cell wt) ${ }^{-1}$, respectively.

\section{Biosynthesis modulation and preparation of radiolabelled ectoine}

The effect of medium osmolality on ectoine biosynthesis was demonstrated using ${ }^{14} \mathrm{C}$-labelled substrates; among several radioactive potential precursors, including glucose, aspartate, proline and glutamate, only glutamate gave significant labelling of ectoine. An experiment done in minimal medium, without $\mathrm{NaCl}$, with $1 \mathrm{M}-\mathrm{NaCl}$ and $1 \mathrm{M}-\mathrm{NaCl}$ plus glycine betaine ( $1 \mathrm{mM})$, involving measurement of the radioactivity in ectoine spots, provided evidence of both an osmolality dependent biosynthetic process and a glycine betaine inhibiting effect $(1.2,22.9$ and $0.3 \%$ of the incorporated radiolabel respectively). Furthermore, the supposed immediate precursor $(N$ acetyldiaminobutyric acid) was also found to be radiolabelled in cells exposed to the highest osmolality in the absence of exogenous osmoprotectant $(1 \cdot 1 \%$ of the incorporated radioactivity); but the biosynthetic pathway remains unclear. Since glutamate was found to be the only efficient precursor, the pathway would therefore not proceed in the same manner as that described by Peters et al. (1990) in E. halochloris and H. elongata, but would rather be like that proposed by Inbar \& Lapidot (1988) for Streptomyces parvulus, starting with glutamate. From these observations, a procedure for producing labelled ectoine from $\mathrm{L}-\left[\mathrm{U}-{ }^{14} \mathrm{C}\right]$ glutamate was developed; addition of the labelled amino acid to growing cells in the presence of Bacto-tryptone gave the highest efficiency (up to $80 \%$ of the radioactivity in the ethanol-soluble fraction was found in ectoine).

In conclusion, ectoine appears to be the main endogenous osmoprotectant in $B$. linens; its biosynthesis and subsequent accumulation are regulated both by the external medium osmolality and exogenously supplied osmoprotectants. Preliminary data, using E. coli cells as a reference model, demonstrated that ectoine appeared as efficient as glycine betaine in relieving osmotic stress (Jebbar et al., 1992). The possibility that ectoine acts in protecting macromolecular structure against destabilizing agents is currently under investigation.

We wish to thank Dr E. A. Galinski, University of Bonn (Germany), for generously providing a sample of authentic ectoine, S. Sinbandhit for helpful assistance in NMR analysis and S. J. R. George for language improvement. Financial support was from CNRS, MEN, and Région Bretagne (Programme Britta).

\section{References}

BAE, J.-H. \& MilleR, K. J. (1992). Identification of two proline transport systems in Staphylococcus aureus and their possible roles in osmoregulation. Applied and Environmental Microbiology 58, 471 475.

Bernard, T., Pocard, J.-A., Perroud, B. \& Le Rudulier. D. (1986). Variations in the response of salt-stressed Rhizobium strains to betaines. Archives of Microbiology 143, 359-364.

Booth, I. R. \& HigGins, C. F. (1990). Enteric bacteria and osmotic stress. Intracellular potassium glutamate as a secondary signal of osmotic stress. FEMS Microbiology Reviews 75, 239-246.

BotsFord, J. L. \& LEwIS, T. A. (1990). Osmoregulation in Rhizobium meliloti: production of glutamic acid in response to osmotic stress. Applied and Environmental Microbiology 56, 488-494.

Cayley, S., Lewis, B. A., Guttman, H. J. \& Record, M. T. (1991). Characterization of the cytoplasm of Escherichia coli K-12 as a function of external osmolarity. Implications for protein-DNA interactions in vivo. Journal of Molecular Biology 222, 281-300.

CsonKa, L. N. (1989). Physiological and genetic responses of bacteria to osmotic stress. Microbiological Reviews 53, 121-147.

Csonka, L. N. \& Hanson, A. D. (1991). Prokaryotic osmoregulation: genetics and physiology. Annual Review of Microbiology 45, 569-606

Dinnbier, U., Limpinsel, E., Schmid, R. \& Bakker, E. P. (1988). Transient accumulation of potassium glutamate and its replacement by trehalose during adaptation of growing cells of Escherichia coli K-12 to elevated sodium chloride concentrations. Archives of Microbiology 150, 348-357.

DunlaP, V. J. \& CsonkA, L. N. (1985). Osmotic regulation of Lproline transport in Salmonella typhimurium. Journal of Bacteriolog! 163, 296-304.

Epstein, W. \& Schultz, S. G. (1965). Cation transport in Escherichic coli. V. Regulation of cation content. Journal of General Physiolog." 49, 221-234.

Galinski, E. A. \& Herzog, R. M. (1990). The role of trehalose as a substitute for nitrogen-containing compatible solutes (Ectothiorhodospira halochloris). Archives of Microbiology 153, 607-613.

Galinski, E. A., Pfeiffer, H. P. \& Trüper, H. G. (1985). 1,4,5.6Tetrahydro-2-methyl-4-pyrimidinecarboxylic acid: a novel cyclic amino acid from halophilic phototrophic bacteria of the genus Ectothiorhodospira. European Journal of Biochemistry 149, 135-139.

Gouesbet, G., Blanco, C., Hamelin, J. \& Bernard, T. (1992). Osmotic adjustment in Brevibacterium ammoniagenes: pipecolic acid accumulation at elevated osmolalities. Journal of General Microbiology 138, 959-965.

Graham, J. E. \& Wilkinson, B. J. (1992). Staphylococcus aureus osmoregulation: roles for choline, glycine betaine, proline, and taurine. Journal of Bacteriology 174, 2711-2716.

Ikuta, S., Matuura, K., Imamura, S., Misaki, H. \& Horiuti, Y. (1977). Oxidative pathway of choline to betaine in the soluble fraction prepared from Arthrobacter globiformis. Journal of Biochemistry 82, 157-163.

IмноF, J. F. (1986). Osmoregulation and compatible solutes in eubacteria. FEMS Microbiology Reviews 39, 57-66.

INBAR, L. \& LAPIDOT, A. (1988). The structure and biosynthesis of new tetrahydropyrimidine derivatives in actinomycin D producer Streptomyces parvulus. Use of ${ }^{13} \mathrm{C}$ and ${ }^{15} \mathrm{~N}$-labeled L-glutamate and ${ }^{13} \mathrm{C}$ and ${ }^{15} \mathrm{~N}$ NMR spectroscopy. Journal of Biological Chemistr. 263 , 16014-16022.

Jebbar, M., Talibart, R., Gloux, K., Bernard, T. \& Blanco, C. (1992). Osmoprotection of Escherichia coli by ectoine: uptake and accumulation characteristics. Journal of Bacteriology 174. $5027-5035$.

JEWELL, J. B. \& KASHKET, E. R. (1991). Osmotically regulated transport of proline by Lactobacillus acidophilus IFO 3532. Applied and Environmental Microbiology 57, 2829-2833.

Kawahara, Y., Ohsumi, T., Yoshihara, Y. \& Ikeda, S. (1989). 
Proline in the osmoregulation of Brevibacterium lactofermentum. Agricultural and Biological Chemistry 53, 2475-2479.

Kawahara, Y., Yoshihara, Y., Ikeda, S. \& Hirose, Y. (1990). Effect of glycine betaine, an osmoprotective compound on the growth of Brevibacterium lactofermentum. Applied Microbiology and Biotechnology 33, 574-577.

Larsen, P. I., Sydnes, L. K., Landfald, B. \& Strøm, A. R. (1987). Osmoregulation in Escherichia coli by accumulation of organic osmolytes: betaines, glutamic acid, and trehalose. Archives of Microbiology 147, 1-7.

LeClerC, J. \& BENOITON, L. (1968). On the selectivity of acylation of unprotected diamino acids. Canadian Journal of Chemistry 46, $1047-1051$.

Measures, J. C. (1975). Role of amino acids in osmoregulation of nonhalophilic bacteria. Nature, London 257, 398-400.

Miller, J. (1972). Experiments in Molecular Genetics. Cold Spring Harbor, NY: Cold Spring Harbor Laboratory.

Perroud, B. \& Le Rudulier, D. (1985). Glycine betaine transport in Escherichia coli: osmotic modulation. Journal of Bacteriology 161, 393-401.

Peters, P., Galinski, E. A. \& Trüper, H. G. (1990). The biosynthesis of ectoine. FEMS Microbiology Letters 71, 157-162.

Regev, R., Peri, R., Gilboa, H. \& Avi-Dor, Y. (1990). ${ }^{13}$ C NMR study of the interrelation between synthesis and uptake of compatible solutes in two moderately halophilic eubacteria. Archives of Biochemistry and Biophysics 278, 106-112.

ROE, J. H. (1955). The determination of sugar in blood and spinal fluid with anthrone reagent. Journal of Biochemistry 212, 335-343.
Smith, L. T. \& Sмiтh, G. M. (1989). An osmoregulated dipeptide in stressed Rhizobium meliloti. Journal of Bacteriology 171. 4714 4717.

Smith, L. T., Smith, G. M. \& Madkour, M. A. (1990). Osmoregulation in Agrobacterium tumefaciens: accumulation of a novel disaccharide is controlled by osmotic strength and glycine betaine. Journal of Bacteriology 172, 6849-6855.

Stock, J. B., Rauch, B. \& Roseman, S. (1977). Periplasmic space in Salmonella typhimurium and Escherichia coli. Journal of Biological Chemistry 252, 7850-7861.

STOREY, R. \& WYN JONES, R. G. (1977). Quaternary ammonium compounds in plants in relation to salt resistance. Phytochemistry $\mathbf{1 6}$. 447-453.

Troll, N. \& Lindsley, J. (1955). A photometric method for the determination of proline. Journal of Biological Chemistry 215. 655-660.

Welsh, D. T., Reed, R. H. \& HerberT, R. A. (1991). The role of trehalose in the osmoadaption of Escherichia coli NCIB 9484: interaction of trehalose, $\mathrm{K}^{+}$and glutamate during osmoadaptation in continuous culture. Journal of General Microbiology 137. 745-750.

Whatmore, A. M. \& ReED, R. H. (1990). Determination of turgor pressure in Bacillus subtilis: a possible role for $\mathrm{K}^{+}$in turgor regulation. Journal of General Microbiology 136, 2521-2526.

Wohlfarth, A., Severin, J. \& Galinski, E. A. (1990). The spectrum of compatible solutes in heterotrophic halophilic eubacteria of the family Halomonadaceae. Journal of General Microbiology 136. 705-712.

Yemm, E. W. \& Cocking, E. C. (1955). The determination of amino acids with ninhydrin. Analyst 80, 209-213. 